\section{Edentulism, Severe Tooth Loss and Lack of Functional Dentition in Elders: A Study in Southern Brazil}

Camila Garcez Ribeiro ${ }^{1}$,Andreia Morales Cascaes ${ }^{2}$, Alexandre Emídio Ribeiro Silva$^{2}$, Lenise Menezes Seerig ${ }^{1}$, Gustavo Giacomelli Nascimento², Flávio Fernando Demarco ${ }^{1,2}$

\author{
'Graduate Program in Epidemiology, \\ UFPel - Universidade Federal de \\ Pelotas, Pelotas, RS, Brazil \\ ${ }^{2}$ Graduate Program in Dentistry, \\ UFPel - Universidade Federal de \\ Pelotas, Pelotas, RS, Brazil \\ Correspondence: Prof. Dr. Flávio \\ Fernando Demarco, Rua Gonçalves \\ Chaves, 457, 96015-568 Pelotas, \\ RS, Brasil. Tel: +55-53-3222-6690. \\ e-mail: flavio.demarco@pq.cnpq.br
}

\begin{abstract}
The aim of this study was to estimate self-reported prevalence of edentulism, severe tooth loss and lack of functional dentition in elders, and to identify potential associated factors. A population based cross-sectional study was carried out with 1,451 elders $(\geq 60$ years), in Pelotas, RS, Brazil. Crude and adjusted prevalence ratios were estimated using Poisson regressions. The prevalence of edentulism, severe tooth loss and lack of functional dentition was $39.3 \%, 60.9 \%$ and $82.7 \%$, respectively. The factors positively associated with tooth loss in the three-degree severity were sex (females), older individuals, low familial income, low level of schooling and having the last dental visit longer than 24 months ago. The high prevalence of tooth loss in its different degrees of severity and the association with preventable factors highlight the need of programs focused on elders, emphasizing the prevention of tooth loss and need for prosthetic rehabilitation.
\end{abstract}

Key Words: tooth loss, aged, cross-sectional studies.

\section{Introduction}

In low- and middle-income countries, including Brazil, population aging and demographic transition have altered the morbidity-mortality profiles, without an adequate health support for the elders (1).

Tooth loss is one of the most common oral health problems among the elderly population (2). Such chronic condition is a result of oral health diseases experienced in life-course, such as dental caries and periodontal disease $(3,4)$. Several studies have demonstrated that tooth loss impacts negatively the quality of life (5), compromising ordinary activities such as phonation, swallowing, chewing and social life (5). Furthermore, it has been associated with systemic health conditions like hypertension (6), obesity and cardiovascular diseases.

According to the Brazilian National Oral Health Survey (SB Brasil 2010), individuals aged 65 to 74 years have on average 25.3 lost teeth and more than half (53.7\%) are completely edentulous (7). In comparison with the 2003 Brazilian National Survey (SB Brasil, 2003), only among the elders the number of missing teeth has not decreased (7).

Self-reported oral health status could be a useful instrument for assessing prevalence of tooth loss and other oral conditions, especially in population-based epidemiological studies (8). Amongst the advantages of this method, it is worth pointing the validity and efficacy of such measure (8). In addition, it reduces costs and timeconsuming clinical exams.

Edentulism has been explored as the outcome in most of the studies investigating tooth loss in elders. Nevertheless, tooth loss should be considered in three different forms according to its level of severity: 1. edentulism, essential for comparisons between studies; 2. severe tooth loss, which impacts directly on the Disability-Adjusted Life Years (DALYs) (10) - a standardized measure that allows to compare the effects of different diseases, conditions and risk factors in the population health and 3. lack of functional dentition, whose reduction is a goal proposed by the WHO, the FDI and the IADR (11). Edentulism is complete tooth loss in both arches (9); severe tooth loss may be described as the presence of at least nine permanent teeth (10), while functional dentition can be defined as the presence of 21 teeth necessary for adequate chewing ability (11).

The World Health Organization (WHO) indicates the number of remaining teeth as an essential data for surveillance in oral health (12). In addition, the WHO also encourages the investigation of risk factors and the impact of tooth loss in the elders, in order to manage intervention programs (12). Even though the literature has pointed out related factors to tooth loss, there is lack of studies among the elderly population.

Given the aforementioned issues, the present study aimed to estimate the prevalence of self-reported edentulism, severe tooth loss and lack of functional dentition in individuals aged 60 or older in a representative sample from a city of Southern Brazil. Furthermore, the study investigated risk factors for the three different levels of tooth loss severity. 


\section{Material and Methods}

The project was approved by the institutional Ethics Committee (Process \# 472.357). All individuals signed the consent form.

A cross-sectional population-based study was conducted in Pelotas between February and July 2014. Pelotas is a medium-size city with approximately 340,000 inhabitants located in Southern Brazil. The study was based on a research consortium discussed in depth elsewhere (13).

The sample size required to investigate the prevalence of tooth loss in elders was calculated based on the following parameters: level of significance of 95\%; prevalence of severe tooth loss (85\%), edentulism (50\%) and lack of functional dentition (90\%) with an acceptable error of 3\%, $4 \%$ and $3 \%$, respectively. A power of $80 \%$ was considered and an effect of 2.0 in addition to 10\% for losses and refusals and $15 \%$ for confounders of the investigation. Thus, the final sample required 1,446 elders.

In order to assure the representativeness of the sample, the sample selection was carried out in two steps: the primary step comprised the census tract from the last National Census, while the inhabited private houses were taken as the secondary step. The 469 urban census tracts were classified by average family income and 133 census tracts were randomly selected. The 4,123 houses included in the sample were systematically selected with a probability proportional to the size of census tracts.

All individuals aged 60 or over living in those houses were invited to participate in the study, except those unable to answer the questionnaire due to cognitive deficit or lack of family or caregiver.

Data were collected at individuals' home by previously trained interviewers using laptops with the Pendragon 6.1 software (Pendragon ${ }^{\circledR}$ Software Corporation, Libertyville, IL, USA). Missing were subjects who could not be located after three attempts or refused to participate in the study.

Tooth loss information was obtained by making the following questions: "How many natural teeth do you have in the upper arch of your mouth? Please, if necessary, count them using your tongue." and "How many natural teeth do you have in the lower arch of your mouth? Please, if necessary, count them using your tongue." The number of teeth related by the elder was noted as a discrete measure. For the analyses, tooth loss was defined as: Edentulism total tooth loss (yes) vs at least one natural tooth (no); Severe Tooth Loss -0 to 8 natural teeth (yes) vs 9 or more natural teeth (no); and Functional Dentition - 0 to 20 natural teeth (yes) vs 21 or more natural teeth (no). Thus, an individual could be included in more than one outcome, since the aim of our study was to estimate the prevalence and associated factors to each form of tooth loss.

The following characteristics were used as independent variables in the analytical models: age in complete years (60-64/65-69/70-74/75-79/80 or more); marital situation (married or living with a partner/divorced or living alone); average family income in Brazilian minimum wages (MW) (up to $1 \mathrm{MW} / 2$ to $3 \mathrm{MW} / 4$ to $5 \mathrm{MW} / 6$ to $9 \mathrm{MW} / 10 \mathrm{MG}$ or more); educational level (up to 3 years $/ 4$ to 7 years/8 to 10 years/ 11 years or more); smoking status (never smoker/ former smoker/current smoker); self-reported diabetes (yes/ no); depression (yes/no) assessed with the Brazilian brief version of the Geriatric Depression Scale (GDS), which considers as depression a score $\geq 5$. Moreover, information regarding use of dental services such as time since last visit (6 months/7 to 12 months/13 to 24 months/more than 24 months) and type of service (public/insurance/ out-of-pocket) was collected. Data quality control was made by administering a short version of the questionnaire by telephone interviews to $10 \%$ of the sample. The Kappa index for the number of teeth question was 0.85 .

All analyses were performed in the software Stata 12.1 (StataCorp., College Station, TX, USA), with the command svy for complex samples. Prevalence rates and respective 95\% confidence intervals of total sample and sample distribution according to the outcome were described. Crude and adjusted prevalence ratios, Wald test for heterogeneity and linear trend were obtained by Poisson regression with a significance level set at 5\%. A hierarchical model guided the multivariable adjusted analysis; thus variables were controlled by variables from the same and distal levels. Demographic variables (sex, age and marital status) and socioeconomic variables (family income and education level) were grouped at the first level (distal). The second level (intermediate) comprised variables related to behavior (smoking) and health conditions (diabetes and depression). Finally, variables related to use of dental services composed the third level (proximal). At each hierarchical level, variables with a $p$-value $<0.20$ in the crude analysis were tested in multiple model and included in the adjusted analyses, following the same criteria for controlling confounders in the subsequent levels.

\section{Results}

Amongst the selected houses, 3,799 were visited and 1,379 included at least one individual aged 60 or over; thus 1,844 individuals were eligible for the study. Among them, 1,491 elders were interviewed (21.3\% losses and refusals). Lost or refusing individuals presented distribution similar to the total sample: $59.3 \%$ were females and $59.5 \%$ were 60 to 69 years old. Only $0.7 \%$ of interviewed elders did not answer the questions about tooth loss and they were excluded from the analyses.

Sample characteristic and distribution of the categories of tooth loss according to demographic, socioeconomic, 
behavioral and health condition are in Table 1. The sample was predominantly composed by females (63.0\%), married or living with a partner (52.7\%), with mean age of 70.7 years. In relation to the socioeconomic level, $42.8 \%$ of the individuals reported to earn 2 to $3 \mathrm{MW}$ and $37.1 \%$ had up to 3 years of study.

Individuals presented on average $8.97( \pm 9.8)$ natural remaining teeth, being $3.5( \pm 5.2)$ in the maxilla and 5.2 $( \pm 5.4)$ in the mandible (data not shown). Prevalence of the dependent variables was $39.3 \%(95 \% \mathrm{Cl} 36.5-42.1)$ for edentulism; $60.9 \%(95 \% \mathrm{Cl} 57.7-64.1)$ for severe tooth loss and $82.7 \%(95 \% \mathrm{Cl} 79.9-85.4)$ to lack of functional dentition.

Table 2 shows a positive association in the crude analysis between edentulism and the following variables: sex, age, marital status, family income, education level, depression, time since last dental visit and type of dental care. In the adjusted analysis was noted a higher prevalence of edentulism among women (PR 1.34; 95\% Cl 1.14-1.57), elders aged 80 or over (PR 2.17;95\% 1 Cl $71-2.75$ ), widowers (PR 1.24;95\% Cl 1.07-1.44), individuals with a family income between 2 to $3 \mathrm{MW}$ (PR 1.37; 95\% $\mathrm{Cl} 0.99-1.89$ ) and those who presented up to 3 years of schooling (PR 2.27; 95\%Cl 1.66-3.08) (Table 2).

Considering the use of dental service, individuals who did not visit the dentist in the last 24 months (PR 3.76; $95 \% \mathrm{Cl}$ 2.72-5.21) and those whose last visit was in the private service compared to insurance (PR 1.43; $95 \% \mathrm{Cl} 1.10$ 1.86) presented greater prevalence of edentulism (Table 2).

According to Table 3, in the crude analysis, almost all variables were positively associated with severe tooth loss, except for diabetes and smoking. In the adjusted analysis, severe tooth loss was more prevalent among the females (PR 1.17; 95\% $\mathrm{Cl} 1.08-1.28)$, those who presented up to 3 years of schooling (PR 2.14; $95 \% \mathrm{Cl} 1.77-2.590$ and those aged 80 or over (PR 1.67; $95 \% \mathrm{Cl} 1.46-1.91)$. Considering the family income, elders who earned up to $1 \mathrm{MW}$ (PR 1.33; 95\% Cl 1.03-1.73), 2 to $3 \mathrm{MW}$ (PR 1.35; 95\% Cl 1.071.72); and 4 to $5 \mathrm{MW}$ (PR 1.37 ; $1.08-1.74$ ) presented higher prevalence of severe tooth loss than those who earned 10 $\mathrm{MW}$ or more. Individuals who visited the dentist longer than the last 24 months (PR 1.88; 95\%C 1.63-2.18) and used private dental service (PR $1.32 ; 95 \% \mathrm{Cl} 1.11-1.57$ ) had greater rates of severe tooth loss (Table 3 ).

Table 4 displays the crude and the adjusted analyses for the lack of functional dentition. In the crude analysis, only diabetes and smoking were not associated with the lack of functional dentition. It was noted that after adjustment, females (PR 1.06; 95\% Cl 1.00-1.11), individuals aged 80 or over (PR $1.19 ; 95 \% \mathrm{Cl} 1.10-1.29)$, those with family income up to $1 \mathrm{MW}$ (PR 1.37; 95\% Cl 1.16-1.61), individuals with less than 3 years of schooling (PR 1.48;
$95 \% \mathrm{Cl} 1.32-1.65)$ and those with 4 to 7 years of schooling (PR 1.49;95\% Cl 1.33-1.66) presented higher prevalence of lacking functional dentition. Moreover, smokers (PR 1.10; 95\% Cl 1.03-1.17), individuals with depression (PR 1.06; 95\% $\mathrm{Cl} 1.01-1.11$ ) and those who visited the dentist over 24 months ago (PR 1.22; 95\% Cl 1.12-1.33) also presented greater rates (Table 4).

\section{Discussion}

Findings from this study demonstrated that only 6.1\% of the elders present all natural teeth and the studied sample has an average of 9 remaining teeth. These data are in agreement with the precarious situation of Brazilian elders, as revealed in the National Oral Health Survey (SBBrasil) (7).

The prevalence of edentulism in the city of Pelotas (39.3\%) was higher compared with some high-income countries, such as Norway (32.1\%) and United Kingdom (11.0\%). On the other hand, it was lower than the prevalence found in São Paulo (68.9\%) and similar to that found in Porto Alegre (39.5\%) (4). The differences observed in the Brazilian studies could be attributed not only to the social disparities among the different regions of Brazil, but also to the sample selection, which included convenience sample, and to the age of included participants, due to lack of standardization (1).

Brazil is one of the five countries that present a standardized rate of severe tooth loss greater than the world average, which was $2.4 \%$ in 2010 (2). In this study, about $60.9 \%$ of the elders presented severe tooth loss. This high prevalence rate was also verified in another study conducted in Pelotas with elders enrolled in the public health service (14). The authors found that $85.1 \%$ of the individuals presented in average 9 natural remaining teeth (14). Since tooth loss is one of the main causes considered in the assessment of disability-adjusted life-years (DALYs), the present findings should be considered in the public health perspective.

Functional dentition has been investigated in different countries. A study conducted in Australia, observed that $75.6 \%$ of the elders from 60 to 71 -years-old presented lack of functional dentition. In 2003, 90.4\% of the Brazilian elders aged 65 to 74 years presented lack of functional dentition (15). The World Health Organization, the World Dental Federation and the International Association for Dental Research have proposed a global goal to 2020, in which at least half the elders should present 21 or more natural teeth (11). Thus, the findings evidence how distant Brazil is from reaching this goal, even in the most developed regions of the country, like the Southeast and South, where tooth loss is less expressive when compared to the other regions (7). 
Table 1. Sample description and distribution of outcomes prevalence according to demographic, socioeconomic, behavioral and health conditions, Pelotas, Brazil, 2014

\begin{tabular}{|c|c|c|c|c|c|c|c|c|}
\hline \multirow[t]{2}{*}{ Variable } & \multicolumn{2}{|c|}{ Total } & \multicolumn{2}{|c|}{ Edentulism } & \multicolumn{2}{|c|}{$\begin{array}{c}\text { Tooth loss } \\
\text { Severe tooth loss }\end{array}$} & \multicolumn{2}{|c|}{$\begin{array}{c}\text { Lack of } \\
\text { functional } \\
\text { dentition }\end{array}$} \\
\hline & $\mathrm{N}$ & $\%$ & $\mathrm{~N}$ & $\%$ & $\mathrm{~N}$ & $\%$ & $\mathrm{~N}$ & $\%$ \\
\hline \multicolumn{9}{|l|}{ Sex $(N=1451)$} \\
\hline Male & 537 & 37.0 & 162 & 30.4 & 286 & 53.7 & 418 & 78.4 \\
\hline Female & 914 & 63.0 & 404 & 44.5 & 591 & 65.1 & 773 & 85.1 \\
\hline \multicolumn{9}{|l|}{ Age $(N=1446)$} \\
\hline 60 to 64 years & 394 & 27.3 & 95 & 24. 2 & 173 & 44.1 & 282 & 71.9 \\
\hline 65 to 69 years & 362 & 25.0 & 115 & 32.1 & 194 & 54.2 & 285 & 79.6 \\
\hline 70 to 74 years & 270 & 18.7 & 110 & 41.0 & 174 & 64.9 & 234 & 87.3 \\
\hline 75 to 79 years & 190 & 13.1 & 97 & 51.1 & 139 & 73.2 & 173 & 91.1 \\
\hline 80 years or over & 230 & 15.9 & 148 & 64.6 & 195 & 85.2 & 214 & 93.5 \\
\hline \multicolumn{9}{|l|}{ Marital Status $(\mathrm{N}=1447)$} \\
\hline Married/with partner & 763 & 52.7 & 238 & 31.4 & 406 & 53.6 & 590 & 77.9 \\
\hline Divorced/single & 225 & 15.6 & 78 & 34.7 & 132 & 58.7 & 179 & 79.6 \\
\hline Widower & 459 & 31.7 & 249 & 54.6 & 337 & 73.9 & 419 & 91.9 \\
\hline \multicolumn{9}{|l|}{ Income (N=1354) } \\
\hline Up to $1 \mathrm{MW}$ & 145 & 10.7 & 64 & 44.4 & 107 & 74.3 & 140 & 97.2 \\
\hline 2 to $3 \mathrm{MW}$ & 579 & 42.8 & 265 & 46.1 & 392 & 68.2 & 516 & 89.7 \\
\hline 4 to $5 \mathrm{MW}$ & 285 & 21.1 & 112 & 39.7 & 181 & 64.2 & 241 & 85.5 \\
\hline 6 to $9 \mathrm{MW}$ & 198 & 14.6 & 58 & 29.3 & 93 & 47.0 & 145 & 73.2 \\
\hline More than $10 \mathrm{MW}$ & 147 & 10.8 & 30 & 20.7 & 47 & 32.4 & 76 & 52.4 \\
\hline \multicolumn{9}{|l|}{ Education ( $N=1437)$} \\
\hline 0 to 3 years & 533 & 37.1 & 279 & 52.6 & 416 & 78.5 & 500 & 94.3 \\
\hline 4 to 7 years & 445 & 31.0 & 192 & 43.3 & 296 & 66.8 & 402 & 90.7 \\
\hline 8 to 10 years & 143 & 9.9 & 38 & 26.8 & 64 & 45.1 & 106 & 74.7 \\
\hline 11 years or beyond & 316 & 22.0 & 54 & 17.3 & 94 & 30.1 & 174 & 55.6 \\
\hline \multicolumn{9}{|l|}{ Smoking $(\mathrm{N}=1446)$} \\
\hline Never & 781 & 54.0 & 307 & 39.6 & 470 & 60.7 & 627 & 80.9 \\
\hline Smoker & 182 & 12.6 & 73 & 40.3 & 119 & 65.8 & 158 & 87.3 \\
\hline Former Smoker & 483 & 33.4 & 184 & 38.3 & 285 & 59.3 & 402 & 83.6 \\
\hline \multicolumn{9}{|c|}{ Diabetes Mellitus (N=1447) } \\
\hline No & 1107 & 76.5 & 421 & 38.3 & 660 & 60.0 & 900 & 81.8 \\
\hline Yes & 340 & 23.5 & 144 & 42.6 & 216 & 63.9 & 289 & 85.5 \\
\hline \multicolumn{9}{|l|}{ Depression $(\mathrm{N}=1395)$} \\
\hline No & 1183 & 84.8 & 436 & 37.0 & 686 & 58.2 & 948 & 80.4 \\
\hline Yes & 212 & 15.2 & 96 & 46.2 & 148 & 71.2 & 192 & 92.3 \\
\hline \multicolumn{9}{|c|}{ Time since last dental visit $(\mathrm{N}=1367)$} \\
\hline 6 months & 372 & 27.2 & 43 & 11.7 & 115 & 31.2 & 235 & 63.7 \\
\hline 7 to 12 months & 152 & 11.1 & 30 & 19.9 & 70 & 46.4 & 108 & 71.5 \\
\hline 13 to 24 months & 129 & 9.4 & 43 & 33.6 & 72 & 56.3 & 109 & 85.2 \\
\hline More than 24 months & 714 & 52.3 & 409 & 57.5 & 556 & 78.2 & 664 & 93.4 \\
\hline \multicolumn{9}{|c|}{ Type of dental service* $(\mathrm{N}=1292)$} \\
\hline Public & 304 & 23.5 & 124 & 41.3 & 196 & 65.3 & 269 & 89.7 \\
\hline Private & 816 & 63.2 & 310 & 38.1 & 480 & 59.0 & 655 & 80.5 \\
\hline Insurance & 172 & 13.3 & 37 & 21.6 & 70 & 40.9 & 120 & 70.2 \\
\hline
\end{tabular}

*Variable with the highest number of losses ( $N=159)$. 
Table 2. Crude and adjusted analyses for edentulism (total tooth loss) according to demographic, socioeconomic, behavioral and health conditions, Pelotas, Brazil, 2014

\begin{tabular}{|c|c|c|c|c|}
\hline Variables & $\begin{array}{c}\text { Crude analysis } \\
\text { PR }(95 \% \mathrm{CI})\end{array}$ & p-value & $\begin{array}{c}\text { Adjusted analysis } \\
\text { PR }(95 \% \mathrm{CI})\end{array}$ & p-value \\
\hline Sex $^{\mathrm{a}}$ & & $<0.001$ & & 0.001 \\
\hline Male & 1.0 & & 1.0 & \\
\hline Female & $1.46(1.25-1.71)$ & & $1.34(1.14-1.57)$ & \\
\hline Age $^{a}$ & & $<0.001^{*}$ & & $<0.001^{*}$ \\
\hline 60 to 64 years & 1.0 & & 1.0 & \\
\hline 65 to 69 years & $1.33(1.03-1.71)$ & & $1.23(0.95-1.59)$ & \\
\hline 70 to 74 years & $1.69(1.36-2.11)$ & & $1.53(1.23-1.90)$ & \\
\hline 75 to 79 years & $2.11(1.64-2.71)$ & & $1.79(1.38-2.32)$ & \\
\hline 80 years or over & $2.67(2.12-3.36)$ & & $2.17(1.71-2.75)$ & \\
\hline Marital Status $^{a}$ & & $<0.001$ & & 0.013 \\
\hline Married/with partner & 1.0 & & 1.0 & \\
\hline Divorced/single & $1.10(0.89-1.37)$ & & $1.12(0.90-1.40)$ & \\
\hline Widower & $1.74(1.51-2.00)$ & & $1.24(1.07-1.44)$ & \\
\hline Income $^{a}$ & & 0.001 & & 0.037 \\
\hline Up to $1 \mathrm{MW}$ & $2.15(1.44-3.19)$ & & $1.14(0.79-1.63)$ & \\
\hline 2 to $3 \mathrm{MW}$ & $2.23(1.55-3.21)$ & & $1.37(0.99-1.89)$ & \\
\hline 4 to $5 \mathrm{MW}$ & $1.92(1.32-2.79)$ & & $1.26(0.90-1.76)$ & \\
\hline 6 to $9 \mathrm{MW}$ & $1.42(0.94-2.13)$ & & $1.11(0.78-1.58)$ & \\
\hline More than $10 \mathrm{MW}$ & 1.0 & & 1.0 & \\
\hline Education $^{\mathrm{a}}$ & & $<0.001^{*}$ & & $<0.001^{*}$ \\
\hline 0 to 3 years & $3.05(2.34-3.98)$ & & $2.27(1.66-3.08)$ & \\
\hline 4 to 7 years & $2.51(1.91-3.31)$ & & $2.17(1.61-2.93)$ & \\
\hline 8 to 10 years & $1.55(1.05-2.29)$ & & $1.55(1.05-2.28)$ & \\
\hline 11 years or more & 1.0 & & 1.0 & \\
\hline Smoking ${ }^{\mathrm{b}}$ & & $0.858^{\ddagger}$ & & - \\
\hline Never & 1.0 & & - & \\
\hline Smoker & $1.02(0.83-1.26)$ & & - & \\
\hline Former Smoker & $0.97(0.82-1.14)$ & & - & \\
\hline Diabetes Mellitus ${ }^{b}$ & & 0.157 & & $0.879^{\mathrm{x}}$ \\
\hline No & 1.0 & & 1.0 & \\
\hline Yes & $1.11(0.96-1.29)$ & & $1.01(0.88-1.17)$ & \\
\hline Depression $^{\mathrm{b}}$ & & 0.013 & & $0.415^{\mathrm{t}}$ \\
\hline No & 1.0 & & 1.0 & \\
\hline Yes & $1.25(1.05-1.48)$ & & $1.08(0.90-1.29)$ & \\
\hline Time since last dental visit ${ }^{c}$ & & $<0.001^{*}$ & & $<0.001^{*}$ \\
\hline 6 months & 1.0 & & 1.0 & \\
\hline 7 to 12 months & $1.70(1.10-2.64)$ & & $1.58(1.02-2.45)$ & \\
\hline 13 to 24 months & $2.88(1.97-4.21)$ & & $2.39(1.64-3.48)$ & \\
\hline More than 24 months & $4.94(3.57-6.83)$ & & $3.76(2.72-5.21)$ & \\
\hline Type of dental service ${ }^{c}$ & & 0.001 & & 0.023 \\
\hline Public & $1.91(1.36-2.68)$ & & $1.29(0.96-1.74)$ & \\
\hline Private & $1.76(1.28-2.43)$ & & $1.43(1.10-1.86)$ & \\
\hline Insurance & 1.0 & & 1.0 & \\
\hline
\end{tabular}

95\%CI: 95\% confidence interval; PR: prevalence ratio; p-value: Wald test for heterogeneity;

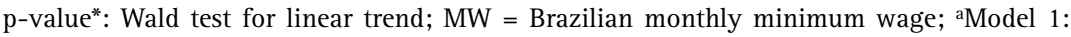
variables from the first analytical level; ${ }^{b}$ Model 2 : variables from the second analytical level; cModel 3: variables from the third analytical level; $\mathrm{x}$ variables removed based on the p-value in the crude analysis $(\mathrm{p}<0.20)$.
The obtained results showed that females, advanced age, low income, low educational level and not visiting a dentist in the last 24 months were positively and independently associated with all types of tooth loss. The analyses demonstrated that the more severe the level of tooth loss, the higher the magnitude of effect measures observed, supporting the importance of the exposure factors investigated in the present study.

Tooth loss is supposed to increase with age, as pointed by previous investigations (16). It could be easily explained by the chronic and cumulative effects of dental caries and periodontal disease, main causes for tooth loss (16). The fact that tooth loss is considered a natural consequence of aging may influence on the behaviors related to its prevention.

Studies conducted in Brazil are unanimous about the predisposition of females to higher prevalence of tooth loss (4). Studies have hypothesized that since women are more aware of treatment needs; they use the dental services more often than men. Consequently, they have been more exposed to dental interventions, which in Brazil are historically mutilating (4). A recent meta-analysis conducted in 2015, revealed that individuals with lower income presented 2.5 higher odds of loosing teeth compared to those with higher income (17). Socioeconomic status is an important predictor of access to information about healthy behaviors and prevention habits (17). Furthermore, the high cost of dental treatments and the restricted access to specialized treatment in the public service also influence individuals from low socioeconomic position to pursue low-cost procedures, like dental extraction (17).

Considering the frequency of dental visit, it was observed that tooth loss is higher among those who use the service less often. It suggests 
Table 3. Crude and adjusted analyses for severe tooth loss according to demographic, socioeconomic, behavioral and health conditions, Pelotas, Brazil, 2014

\begin{tabular}{|c|c|c|c|c|}
\hline Variables & $\begin{array}{l}\text { Crude analysis } \\
\text { PR }(95 \% \mathrm{CI})\end{array}$ & $\mathrm{p}$-value & $\begin{array}{l}\text { Adjusted analysis } \\
\text { PR }(95 \% \mathrm{CI})\end{array}$ & $\mathrm{p}$-value \\
\hline $\operatorname{Sex}^{\mathrm{a}}$ & & $<0.001$ & & $<0.001$ \\
\hline Male & 1.0 & & 1.0 & \\
\hline Female & $1.21(1.11-1.33)$ & & $1.17(1.08-1.28)$ & \\
\hline Age $^{a}$ & & $<0.001^{*}$ & & $<0.001^{*}$ \\
\hline 60 to 64 years & 1.0 & & 1.0 & \\
\hline 65 to 69 years & $1.23(1.06-1.43)$ & & $1.16(1.01-1.34)$ & \\
\hline 70 to 74 years & $1.47(1.26-1.71)$ & & $1.37(1.19-1.58)$ & \\
\hline 75 to 79 years & $1.66(1.42-1.93)$ & & $1.45(1.25-1.68)$ & \\
\hline 80 years or over & $1.93(1.67-2.22)$ & & $1.67(1.46-1.91)$ & \\
\hline Marital Status ${ }^{\mathrm{a}}$ & & $<0.001$ & & $0.335^{\mathrm{t}}$ \\
\hline Married/with partner & 1.0 & & 1.0 & \\
\hline Divorced/single & $1.09(0.96-1.24)$ & & $1.10(0.97-1.24)$ & \\
\hline Widower & $1.38(1.25-1.52)$ & & $1.06(0.97-1.16)$ & \\
\hline Income $^{a}$ & & $<0.001^{*}$ & & 0.016 \\
\hline Up to $1 \mathrm{MW}$ & $2.29(1.70-3.09)$ & & $1.33(1.02-1.73)$ & \\
\hline 2 to $3 \mathrm{MW}$ & $2.10(1.58-2.79)$ & & $1.35(1.07-1.72)$ & \\
\hline 4 to $5 \mathrm{MW}$ & $1.98(1.50-2.61)$ & & $1.37(1.08-1.74)$ & \\
\hline 6 to $9 \mathrm{MW}$ & $1.45(1.08-1.95)$ & & $1.18(0.92-1.53)$ & \\
\hline More than $10 \mathrm{MW}$ & 1.0 & & 1.0 & \\
\hline Education $^{\mathrm{a}}$ & & $<0.001^{*}$ & & $<0.001^{*}$ \\
\hline 0 to 3 years & $2.61(2.18-3.13)$ & & $2.14(1.77-2.59)$ & \\
\hline 4 to 7 years & $2.22(1.83-2.70)$ & & $1.97(1.63-2.39)$ & \\
\hline 8 to 10 years & $1.50(1.15-1.95)$ & & $1.51(1.18-1.94)$ & \\
\hline 11 years or more & 1.0 & & 1.0 & \\
\hline Smoking ${ }^{\mathrm{b}}$ & & $0.255^{\mathrm{t}}$ & & \\
\hline Never & 1.0 & & - & \\
\hline Smoker & $1.08(0.96-1.22)$ & & - & \\
\hline Former Smoker & $0.98(0.88-1.09)$ & & - & \\
\hline Diabetes Mellitus ${ }^{\mathrm{b}}$ & & 0.156 & & $0.736^{t}$ \\
\hline No & 1.0 & & 1.0 & \\
\hline Yes & $1.07(0.98-1.16)$ & & $1.01(0.94-1.10)$ & \\
\hline Depression $^{\mathrm{b}}$ & & 0.001 & & 0.072 \\
\hline No & 1.0 & & 1.0 & \\
\hline Yes & $1.22(1.09-1.37)$ & & $1.10(0.99-1.23)$ & \\
\hline Time since last dental visit ${ }^{c}$ & & $<0.001^{*}$ & & $<0.001^{*}$ \\
\hline 6 months & 1.0 & & 1.0 & \\
\hline 7 to 12 months & $1.49(1.21-1.83)$ & & $1.30(1.05-1.62)$ & \\
\hline 13 to 24 months & $1.80(1.46-2.22)$ & & $1.50(1.22-1.85)$ & \\
\hline More than 24 months & $2.51(2.12-2.97)$ & & $1.88(1.63-2.18)$ & \\
\hline Type of dental service ${ }^{c}$ & & $<0.001$ & & 0.005 \\
\hline Public & $1.60(1.31-1.94)$ & & $1.22(1.01-1.48)$ & \\
\hline Private & $1.44(1.19-1.75)$ & & $1.32(1.11-1.57)$ & \\
\hline Insurance & 1.0 & & 1.0 & \\
\hline
\end{tabular}

95\%CI: 95\% confidence interval; PR: prevalence ratio; $p$-value: Wald test for heterogeneity; p-value*: Wald test for linear trend; $M W=$ Brazilian monthly minimum wage; ${ }^{*}$ Model 1 : variables from the first analytical level; ${ }^{b}$ Model 2: variables from the second analytical level; 'Model 3: variables from the third analytical level; $\mathrm{x}$ variables removed based on the p-value in the crude analysis $(\mathrm{p}<0.20)$. that the lack of routine dental visits also contribute to the precarious oral health conditions of the Brazilian elders (18). On the other hand, the frequency of visits may be determined by the lack of natural teeth (18), since some elders consider the total tooth loss as reason for not visiting a dentist.

Lower prevalence rates of edentulism and severe tooth loss were verified among those elders who used health insurance. According to a previous study conducted in Brazil, individuals who had oral health insurance presented greater mean of remaining and sound teeth (19). A possible explanation for these findings could be the following scenario: elders who did not have access to public service used to pay out of the pocket to have their teeth extracted. In the oral health insurance context, the dentist must justify the dental extraction with radiographic exams in order to be paid, whereas in the private service there is no control of treatment indication. Even though Brazil has adopted a National Oral Health Policy in 2004, which included universal care and focused on health promotion and prevention, this age group has experienced the old public system, which was based on pain relief and dental extraction (1).

Individuals that were married or living with a partner presented lower prevalence of edentulism, as corroborated by a study conducted in Mexico (20). The literature has pointed out marriage as a protective factor to health outcomes, due to environmental, social and psychological factors (21).

The lack of functional dentition was positively associated with smoking and depression. Elderly smokers and former-smokers were more susceptible to this outcome, as demonstrated in previous studies (4). Smoking is a risk factor to periodontitis, as it impacts on the host immune response leading to an exacerbated tissue destruction (22). In relation to depression, an 
Table 4. Crude and adjusted analyses for lack of functional dentition according to demographic, socioeconomic, behavioral and health conditions, Pelotas, Brazil, 2014

\begin{tabular}{|c|c|c|c|c|}
\hline Variables & $\begin{array}{c}\text { Crude analysis } \\
\text { PR }(95 \% \mathrm{CI})\end{array}$ & p-value & $\begin{array}{c}\text { Adjusted analysis } \\
\text { PR }(95 \% \mathrm{CI})\end{array}$ & $\mathrm{p}$-value \\
\hline $\operatorname{Sex}^{\mathrm{a}}$ & & 0.002 & & 0.030 \\
\hline Male & 1.0 & & 1.0 & \\
\hline Female & $1.09(1.03-1.14)$ & & $1.06(1.00-1.11)$ & \\
\hline Age $^{a}$ & & $<0.001^{*}$ & & $<0.001^{*}$ \\
\hline 60 to 64 years & 1.0 & & 1.0 & \\
\hline 65 to 69 years & $1.11(1.03-1.19)$ & & $1.08(1.01-1.15)$ & \\
\hline 70 to 74 years & $1.21(1.12-1.32)$ & & $1.17(1.08-1.25)$ & \\
\hline 75 to 79 years & $1.27(1.17-1.37)$ & & $1.17(1.09-1.26)$ & \\
\hline 80 years or over & $1.30(1.20-1.41)$ & & $1.19(1.10-1.29)$ & \\
\hline Marital Status $^{\mathrm{a}}$ & & $<0.001$ & & 0.154 \\
\hline Married/with partner & 1.0 & & 1.0 & \\
\hline Divorced/single & $1.02(0.94-1.11)$ & & $1.02(0.95-1.10)$ & \\
\hline Widower & $1.18(1.12-1.25)$ & & $1.05(1.00-1.11)$ & \\
\hline Income $^{a}$ & & $<0.001^{*}$ & & $<0.001^{*}$ \\
\hline Up to $1 \mathrm{MW}$ & $1.85(1.53-2.25)$ & & $1.37(1.16-1.61)$ & \\
\hline 2 to $3 \mathrm{MW}$ & $1.71(1.41-2.07)$ & & $1.33(1.13-1.56)$ & \\
\hline 4 to $5 \mathrm{MW}$ & $1.63(1.35-1.97)$ & & $1.32(1.12-1.56)$ & \\
\hline 6 to $9 \mathrm{MW}$ & $1.40(1.14-1.71)$ & & $1.25(1.04-1.49)$ & \\
\hline More than $10 \mathrm{MW}$ & 1.0 & & 1.0 & \\
\hline Education $^{\mathrm{a}}$ & & $<0.001^{*}$ & & $<0.001$ \\
\hline 0 to 3 years & $1.70(1.50-1.92)$ & & $1.48(1.32-1.65)$ & \\
\hline 4 to 7 years & $1.63(1.44-1.85)$ & & $1.49(1.33-1.66)$ & \\
\hline 8 to 10 years & $1.34(1.15-1.57)$ & & $1.30(1.12-1.50)$ & \\
\hline 11 years or more & 1.0 & & 1.0 & \\
\hline Smoking ${ }^{\mathrm{b}}$ & & 0.075 & & 0.007 \\
\hline Never & 1.0 & & 1.0 & \\
\hline Smoker & $1.08(1.01-1.15)$ & & $1.10(1.03-1.17)$ & \\
\hline Former Smoker & $1.03(0.97-1.09)$ & & $1.06(1.01-1.12)$ & \\
\hline Diabetes Mellitus ${ }^{\mathrm{b}}$ & & 0.094 & & $0.427^{\mathrm{t}}$ \\
\hline No & 1.0 & & 1.0 & \\
\hline Yes & $1.05(0.99-1.10)$ & & $1.02(0.98-1.06)$ & \\
\hline Depression $^{\mathrm{b}}$ & & $<0.001$ & & 0.021 \\
\hline No & 1.0 & & 1.0 & \\
\hline Yes & $1.15(1.09-1.21)$ & & $1.06(1.01-1.11)$ & \\
\hline Time since last dental visit ${ }^{c}$ & & $<0.001^{*}$ & & $<0.001^{*}$ \\
\hline 6 months & 1.0 & & 1.0 & \\
\hline 7 to 12 months & $1.12(0.98-1.29)$ & & $1.06(0.93-1.20)$ & \\
\hline 13 to 24 months & $1.34(1.18-1.52)$ & & $1.20(1.08-1.33)$ & \\
\hline More than 24 months & $1.47(1.32-1.63)$ & & $1.22(1.12-1.33)$ & \\
\hline Type of dental service ${ }^{c}$ & & $<0.001$ & & 0.192 \\
\hline Public & $1.28(1.14-1.43)$ & & $1.09(0.98-1.21)$ & \\
\hline Private & $1.15(1.02-1.28)$ & & $1.10(0.99-1.22)$ & \\
\hline Insurance & 1.0 & & 1.0 & \\
\hline
\end{tabular}

95\%CI: 95\% confidence interval; PR: prevalence ratio; p-value: Wald test for heterogeneity;

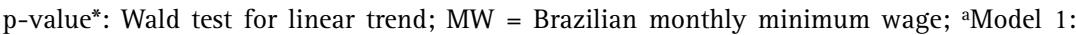
variables from the first analytical level; ${ }^{b}$ Model 2: variables from the second analytical level; 'Model 3: variables from the third analytical level; $x$ variables removed based on the p-value in the crude analysis $(\mathrm{p}<0.20)$.
American study revealed higher tooth loss among individuals diagnosed with depression and anxiety (23). According to previous studies, depression could increase the risk of periodontitis and dental caries by physiological and psychological pathways (24).

Some limitations of the present study should be pointed out. The first one is the use of self-reported tooth loss. Even though this measure could not be considered as the gold-standard, population-based epidemiological studies worldwide have been using such approach $(8,25)$. The second limitation refers to the cross-sectional design, which has difficulty to verify temporal relationships between the outcome and independent variables; it precludes establishing causal inference to the observed findings.

The population-based sample with a low percentage of losses and refusals assured the internal and external validity of this study, since the findings may be transposed to similar populations. Furthermore, the study explores risk factors not previously investigated in a sample composed only by elders. It is also worth to emphasize that besides edentulism, this study investigated other outcomes such as severe tooth loss and lack of functional dentition.

In conclusion, the high prevalence rates of tooth loss at different levels indicated a great need of dental prostheses in elders. Even though the Brazilian Health System offers dental prosthesis to the population, access to this service is restricted and should be expanded. The present findings could indicate that advances are needed for planning health services in the context of Primary Health Care, concentrating efforts on the prevention of tooth loss. In addition, oral rehabilitation should be a priority, given the high rates of edentulism and severe tooth loss in the population. Thus, public resources and Regional Prosthesis Laboratories should focus 
not only on complete dentures, but also on partial dentures.

\section{Resumo}

0 objetivo deste estudo foi estimar as prevalências autorreferidas de edentulismo, perda dentária severa e ausência de dentição funcional em idosos, assim como identificar potenciais fatores associados. Um estudo transversal de base populacional foi realizado com 1.451 idosos ( $\geq 60$ anos), em Pelotas, RS, Brasil. Razões de prevalência brutas e ajustadas foram estimadas por meio de regressões de Poisson. As prevalências verificadas foram $39,3 \%$ para edentulismo, 60,9\% para perda dentária severa e $82,7 \%$ para ausência de dentição funcional. Os fatores associados positivamente à perda dentária nos seus três diferentes graus de severidade foram sexo feminino, idade avançada, baixa renda familiar, baixa escolaridade e última consulta odontológica há mais de 24 meses. As altas prevalências de perda dentária nos seus diferentes graus de severidade e a constatação de fatores associados passiveis de intervenção alertam para necessidade de medidas e programas que priorizem a faixa etária idosa com ênfase na prevenção da perda dentária e na reabilitação protética.

\section{References}

1. Moreira RS, Nico LS, Tomita NE, Ruiz T. Oral health of Brazilian elderly: a systematic review of epidemiologic status and dental care access. Cad Saude Publica 2005;21:1665-1675.

2. Kassebaum NJ, Bernabe E, Dahiya M, Bhandari B, Murray CJ, Marcenes W. Global burden of severe tooth loss: a systematic review and metaanalysis. J Dent Res 2014;93:20S-28S.

3. Kossioni $A E$, Dontas $A S$. The stomatognathic system in the elderly. Useful information for the medical practitioner. Clin Interv Aging. 2007;2:591-597.

4. Gaio EJ, Haas AN, Carrard VC, Oppermann RV, Albandar J, Susin C. Oral health status in elders from South Brazil: a population-based study. Gerodontology 2012;29:214-223.

5. Gerritsen AE, Allen PF, Witter DJ, Bronkhorst EM, Creugers NH. Tooth loss and oral health-related quality of life: a systematic review and meta-analysis. Health Qual Life Outcomes 2010;8:126.

6. Peres MA, Tsakos G, Barbato PR, Silva DA, Peres KG. Tooth loss is associated with increased blood pressure in adults - a multidisciplinary population-based study. J Clin Periodontol 2012;39:824-833.

7. Brasil. SB Brasil 2010. National Oral Health Survey - Principal Findings. Secretariat of Health Care. Department of Primary Care. General Coordination of Oral Health. Brasilia: Ministry of Health; 2011. p. 92.

8. Pitiphat W, Garcia RI, Douglass CW, Joshipura KJ. Validation of selfreported oral health measures. J Public Health Dent 2002;62:122-128.

9. Medina-Solis CE, Perez-Nunez R, Maupome G, Casanova-Rosado JF. Edentulism among Mexican adults aged 35 years and older and associated factors. Am J Public Health 2006;96:1578-1581.
10. Marcenes W, Kassebaum NJ, Bernabe E, Flaxman A, Naghavi M, Lopez A, et al.. Global burden of oral conditions in 1990-2010: a systematic analysis. J Dent Res 2013;92:592-597.

11. Hobdell M, Petersen PE, Clarkson J, Johnson N. Global goals for oral health 2020. Int Dent J. 2003;53:285-288.

12. Petersen $P E$, Yamamoto T. Improving the oral health of older people: the approach of the WHO Global Oral Health Programme. Community Dent Oral Epidemiol 2005;33:81-92.

13. Barros AJ, Menezes AM, Santos IS, Assuncao MC, Gigante DP, Fassa $A G$, et al.. UFPel's epidemiology MSc program based on research consortium: an innovative experience. Rev Bras Epidemiol 2008;11:11.

14. Silva $A E$, Demarco FF, Feldens $C A$. Oral health-related quality of life and associated factors in Southern Brazilian elderly. Gerodontology 2015;32:35-45.

15. Hugo FN, Hilgert JB, Sousa ML, Silva DD, Pucca GA Jr. Correlates of partial tooth looss and edentulism in Brazilian elderly. Community Dent Oral Epidemiol 2007;35:224-232.

16. Chestnutt IG, Binnie VI, Taylor MM. Reasons for tooth extraction in Scotland. J Dent 2000;28:295-297.

17. Seerig LM, Nascimento GG, Peres MA, Horta BL, Demarco FF. Tooth loss in adults and income: Systematic review and meta-analysis. J Dent 2015;43:1051-1059.

18. Moreira RS, Nico LS, Tomita NE. Spatial risk and factors associated with edentulism among elderly persons in Southeast Brazil. Cad Saude Publica 2011;27:2041-2054.

19. Silva DD, Sousa ML, Wada RS. Self-perception and oral health conditions in an elderly population. Cad Saude Publica 2005;21:12511259.

20. Islas-Granillo $H$, Borges-Yanez SA, Lucas-Rincon SE, Medina-Solis $\mathrm{CE}$, Casanova-Rosado AJ, Marquez-Corona $\mathrm{ML}$, et al.. Edentulism risk indicators among Mexican elders 60-year-old and older. Arch Gerontol Geriatr 2011;53:258-262.

21. Goldman N, Korenman S, Weinstein R. Marital status and health among the elderly. Soc Sci Med 1995;40:1717-1730.

22. Preshaw PM, Seymour RA, Heasman PA. Current concepts in periodontal pathogenesis. Dent Update 2004;31:570-572,574-578.

23. Okoro CA, Strine TW, Eke PI, Dhingra SS, Balluz LS. The association between depression and anxiety and use of oral health services and tooth loss. Community Dent Oral Epidemiol 2012;40:134-144.

24. Rosania $A E$, Low KG, McCormick CM, Rosania DA. Stress, depression, cortisol, and periodontal disease. J Periodontol 2009;80:260-266.

25. Peres MA, Barbato PR, Reis SC, Freitas $\mathrm{CH}$, Antunes JL. Tooth loss in Brazil: analysis of the 2010 Brazilian Oral Health Survey. Rev Saude Publica 2013;47:78-89.
Received November 30, 2015 Accepted March 28, 2016 